\title{
Characterizing the HIV epidemic in the prairie provinces
}

\author{
Marissa L Becker $\mathrm{MD}^{1,2,3,4}$, Ken Kasper $\mathrm{MD}^{1,4}$, Carla Pindera $\mathrm{RN}^{4}$, Mary Cheang $\mathrm{PhD}^{3}$, Debbie Rodger $\mathrm{MD}^{5}$, \\ Stephen Sanche $\mathrm{MD}^{6}$, Stuart Skinner $\mathrm{MD}^{6}$, M John Gill MD MSc${ }^{7,8}$ \\ ML Becker, K Kasper, C Pindera, et al. Characterizing the HIV \\ epidemic in the prairie provinces. Can J Infect Dis Med

\section{La caractérisation de l'épidémie de VIH dans les provinces des Prairies} Microbiol 2012;23(1):19-22.

BACKGROUND: The numbers and demographics of HIV-positive patients in care between 2003 and 2007 in the prairie provinces were examined.

METHODS: Estimates of HIV-positive patients presenting to care between 2003 and 2007 were obtained from four clinic registries in Manitoba, Saskatchewan and southern Alberta. Detailed data were collected from clinical records of new patients in 2007.

RESULTS: By the end of December 2007, 2263 HIV-positive persons were in care in Manitoba, Saskatchewan and southern Alberta. Males and females accounted for 1674 (74.0\%) and 589 of the cases, respectively. Overall, there was a $12 \%$ increase per year in new HIV cases to care between 2003 and $2007(\mathrm{P}=0.026)$, with the rate of increase for males being $60 \%$ higher than for females over this time period $(\mathrm{P}=0.002)$. In 2007 , there were 222 new HIV cases to care $(37.4 \%$ female). Heterosexual contact was the most common HIV risk, but diversity was seen across sites with frequent injection drug use and men who have sex with men risk in Saskatchewan and southern Alberta, respectively. The Aboriginal population remains heavily over-represented, with approximately $36.0 \%$ of new cases being Aboriginal. Late presentation was common across all care sites, with $35.1 \%$ of cases presenting with CD4 counts of less than 200 cells $/ \mathrm{mm}^{3}$. DISCUSSION: Heterosexual risk is the most common risk reported for HIV acquisition, but injection drug use risk remains significant in Saskatchewan. Aboriginals are over-represented at all sites, and in Saskatchewan accounted for the majority of new cases seen. In contrast to national trends, numbers of new and late diagnoses are increasing in the praire provinces, and this has significant treatment implications and potential public health consequences. Further efforts need to be made to facilitate earlier testing and linkage to care.

Key Words: Aboriginal; Care; Epidemiology; HIV; Prairie provinces

$\mathrm{T}$ here is increasing recognition of the complexity and heterogeneity of the global HIV epidemic, and this remains true in Canada. By the end of 2007, the Public Health Agency of Canada (PHAC) indicated that there had been an estimated 64,800 persons infected with HIV/AIDS (PHA) in Canada $(1,2)$. Of these PHAs, certain populations, including Aboriginals and persons from endemic countries remain over-represented. Whereas the Aboriginal population constitutes approximately $3.75 \%$ of the total population, they represent approximately $7.5 \%$ of prevalent HIV infections nationally (2). In addition, according to the 2001 census, $2.1 \%$ of the Canadian population was born in HIV-endemic countries. However, $15.0 \%$ of infections reported in 2005 had heterosexual endemic exposure as their primary risk factor for infection (2).

While the largest numbers of HIV-positive tests come from Ontario, Quebec and British Columbia, areas in the prairie provinces are seeing the greatest increase in the number of HIV-positive persons diagnosed
HISTORIQUE : Les chercheurs ont examiné le nombre et la démographie des patients positifs au VIH soignés entre 2003 et 2007 dans les provinces des Prairies.

MÉTHODOLOGIE : Les chercheurs ont pu évaluer le nombre de patients positifs au VIH qui ont consulté pour la première fois entre 2003 et 2007 d'après quatre registres cliniques du Manitoba, de la Saskatchewan et du sud de l'Alberta. Ils ont également recueilli les données détaillées des dossiers cliniques de nouveaux patients en 2007. RÉSULTATS : À la fin de décembre 2007, 2263 personnes positives au VIH étaient soignées au Manitoba, en Saskatchewan et dans le sud de l'Alberta. Les hommes et les femmes représentaient $1674(74,0 \%)$ et 589 cas, respectivement. Dans l'ensemble, on a constaté une augmentation annuelle de $12 \%$ des nouveaux cas de VIH soignés entre 2003 et $2007(\mathrm{P}=0,026)$, le taux d'augmentation pour les hommes étant $60 \%$ plus élevé que pour les femmes $(\mathrm{P}=0,002)$. En 2007, on a recensé 222 nouveaux cas de VIH soignés (37,4\% de femmes). Le contact hétérosexuel représentait le principal risque de $\mathrm{VIH}$, mais on remarquait une diversité selon les lieux, le risque posé par la consommation fréquente de drogues par injection et par les relations sexuelles entre hommes étant observé en Saskatchewan et au sud de l'Alberta, respectivement. La population autochtone demeure lourdement surreprésentée, puisqu'environ 36,0\% des nouveaux cas étaient d'origine autochtone. Une présentation tardive était fréquente partout, la numération de $\mathrm{CD}_{4}$ étant inférieure à 200 cellules $/ \mathrm{mm}^{3}$ à la présentation dans $35,1 \%$ des cas.

EXPOSÉ : Les contacts hétérosexuels constituent le principal risque déclaré d'acquisition du VIH, mais la consommation de drogues par injection demeure importante en Saskatchewan. Les Autochtones sont surreprésentés partout, et en Saskatchewan, ils représentent la majorité des nouveaux cas observés. Contrairement aux tendances nationales, le nombre de nouveaux diagnostics et de diagnostics tardifs augmente dans les provinces des Prairies, ce qui a des répercussions thérapeutiques importantes et des conséquences potentielles en matière de santé publique. Il faut faire davantage d'efforts pour favoriser la tenue de tests et des mises en relation plus rapides vers les soins.

(1). Little is known about the epidemiology of HIV in the prairie provinces, and it is important to determine whether certain populations are over-represented within this region. The diversity of the Canadian population and the over-representation of some ethnic groups highlights the need for adaptable and culturally sensitive HIV prevention, testing and care programs. More than $43.0 \%$ of Canada's Aboriginal population live in the three prairie provinces, comprising $15.5 \%, 14.9 \%$ and $5.8 \%$ of the populations of Manitoba, Saskatchewan and Alberta, respectively (3). Winnipeg (Manitoba) has the largest urban Aboriginal population in Canada, followed by Edmonton (Alberta). In addition, Manitoba and Alberta also have large immigrant populations, comprising $13.3 \%$ and $16.2 \%$, respectively of the total population (4), with a high proportion from HIV-endemic countries.

In addition to appreciating the sociodemographic profile of the HIV-positive population in the prairie provinces, it is important to be aware of their care patterns and presentations. In Canada, an

${ }^{1}$ Department of Medicine; ${ }^{2}$ Department of Medical Microbiology; ${ }^{3}$ Department of Community Health Sciences, University of Manitoba;

${ }^{4}$ Manitoba HIV Program, Winnipeg, Manitoba; ${ }^{5}$ Regina Qu'Appelle Health; ${ }^{6}$ Department of Medicine, University of Saskatchewan, Regina,

Saskatchewan; ${ }^{7}$ Department of Medicine, University of Calgary; ${ }^{8}$ Southern Alberta Clinic, Calgary, Alberta

Correspondence: Dr Marissa L Becker, Centre for Global Public Health, R070 Medical Rehabilitation Building, 771 McDermot Avenue,

Winnipeg, Manitoba R3E 0T6. Telephone 204-272-3151, fax 204-789-3718, e-mail beckerm@cc.umanitoba.ca 
TABLE 1

Current HIV-positive cases in care according to province

\begin{tabular}{lcccc}
\hline & Manitoba & Saskatchewan & Alberta & Total \\
\hline Male & $546(67.9)$ & $218(62.5)$ & $910(82.0)$ & $1674(74.0)$ \\
Female & $258(32.1)$ & $131(37.5)$ & $200(18.0)$ & $589(26.0)$ \\
Total, n & 804 & 349 & 1110 & 2263 \\
\hline
\end{tabular}

Data presented as $n$ (\%), unless otherwise indicated

TABLE 2

Rate of new HIV-positive cases to care according to province, between 2003 and 2007

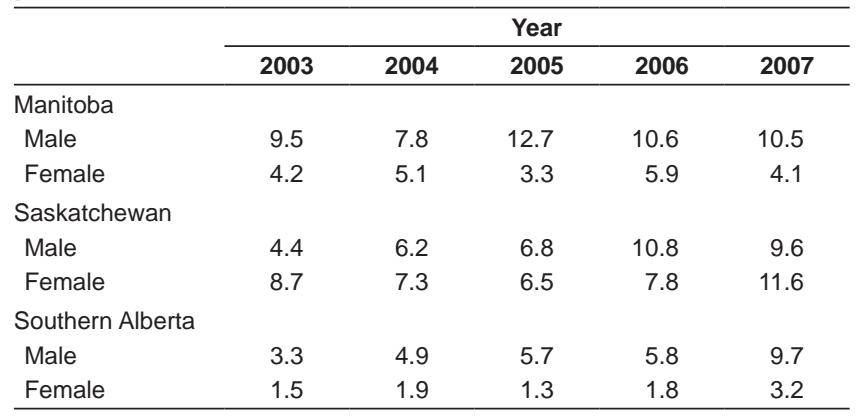

Data presented as rate per 100,000 persons

estimated $27.0 \%$ of HIV-positive persons were unaware of their HIV status (2). As well, in Manitoba, it was estimated that approximately one-third of patients present to care quite late, presenting by definition with AIDS (Personal commnuicaiton, Kasper K, Manitoba HIV Program, August 5, 2009). Further investigaton of these issues in the prairie region is critical, because it can provide the HIV prevention and care programming in these provinces with much needed information to support essential evidence-based approaches to earlier HIV diagnosis and linkage to care in the prairie region.

In an effort to better understand the current demographic profiles of HIV-positive patients in care in the prairie provinces, a chart review was performed. The goal of the chart review was to describe the demographics and presentation of HIV-positive patients in care and to further examine the existing challenges in providing care in Manitoba, Saskatchewan and Alberta.

\section{METHODS}

A retrospective chart review was conducted on HIV-positive persons in care at outpatient clinics in Manitoba, Saskatchewan and southern Alberta. In Manitoba, data were gathered from the two outpatient clinics in the Manitoba HIV Program, the HIV outpatient clinic at the Health Sciences Centre and the Nine Circles Community Health Centre in Winnipeg. In Saskatchewan, data were collected from the Infectious Diseases Clinic in Regina and the Positive Living Program in Saskatoon. Data on HIV-positive persons in care in southern Alberta were captured from the Southern Alberta Clinic in Calgary. These clinics provide care to more than $95 \%$ of HIV-positive patients in care within their respective regions.

Data capture tools were used to identify the number of newly reported HIV cases and the number of persons who accessed HIV care from clinic records between 2003 and 2007. Cases were defined as an HIV-positive individual (adult or child) seen at least once in a clinic during the calendar year. In addition, detailed information was collected on new cases presenting to care from January 1 to December 31, 2007. New cases were defined as a new HIV-positive person seen in a clinic or in a hospital during the 2007 calendar year. Persons transferred from any other clinic or provinces were excluded. Variables collected included sex, age, transmission risk, ethnicity, CD4 count at presentation, clinical presentation and hepatitis $\mathrm{C}$ status. Ethnicity was captured as either self-reported Aboriginal or non-Aboriginal. Risk factors for transmission included heterosexual from a high-risk endemic region, injection drug use (IDU) and men who have sex with men (MSM).
TABLE 3

Poisson regression analysis of new HIV cases to care, according to province, between 2003 and 2007

\begin{tabular}{lccc}
\hline & Rate ratio & $95 \% \mathbf{C l}$ & $\mathbf{P}$ \\
\hline Overall & & & \\
Year & 1.12 & $1.01-1.24$ & 0.026 \\
Male & 1.60 & $1.19-2.13$ & 0.002 \\
Southern Alberta & Reference & - & - \\
Manitoba & 1.88 & $1.28-2.78$ & 0.001 \\
Saskatchewan & 2.04 & $1.39-2.98$ & $<0.0001$ \\
$\begin{array}{l}\text { Province } \\
\text { Manitoba }\end{array}$ & & & \\
$\quad$ Year & 1.04 & $0.96-0.99$ & 0.37 \\
$\quad$ Male & 2.26 & $1.79-4.03$ & $<0.0001$ \\
Saskatchewan & & & \\
$\quad$ Year & 1.14 & $1.06-1.21$ & 0.001 \\
$\quad$ Male & 0.90 & $0.72-0.65$ & 0.386 \\
Southern Alberta & & & \\
$\quad$ Year & 1.25 & $1.14-1.43$ & $<0.0001$ \\
$\quad$ Male & 3.08 & $2.25-6.91$ & $<0.0001$ \\
\hline
\end{tabular}

Ethics approval was obtained from the research ethics boards at the University of Manitoba (Winnipeg), the University of Saskatchewan (Regina), the Regina Qu'Appelle Health, and the University of Calgary.

\section{Statistical analysis}

Data were entered into a Microsoft Access database (Microsoft Corporation, USA) and analyzed using SAS version 9.2 (SAS Inc, USA). Groups were compared and associations tested using $\chi^{2}$ analysis. Rates of new cases to care were calculated using Statistics Canada population data (5). Poisson regression analysis was used to compare the trends of rates of new cases between 2003 and 2007. Statistical significance was set at 0.05 . Multiple logistic regression modelling was performed to provide independent risk factors for late presentation (combined opportunistic infection [OI] or CD4 $<200$ cells $/ \mathrm{mm}^{3}$ ). Adjusted OR with 95\% CI was estimated.

\section{RESULTS}

Trends in access to care

By the end of 2007, there were 2263 HIV-positive persons in care in Manitoba, Saskatchewan and southern Alberta (Table 1). Males accounted for 1674 of the cases $(74.0 \%)$ and females for $589(26.0 \%)$ cases. Alberta had the largest number of persons in care (49\% of the total), followed by Manitoba (36\%) and Saskatchewan (15\%). Approximately one-third of cases in care in Manitoba and Saskatchewan were women, but with fewer in Alberta (18\%).

Rates of new cases to care across the prairie provinces are shown in Table 2, with results from Poisson regression analysis shown in Table 3. In the prairie region, overall there was a $12 \%$ increase per year in new HIV cases to care between 2003 and $2007(\mathrm{P}=0.026)$, with male rates being $60 \%$ higher than female rates over this time period $(\mathrm{P}=0.002)$. Compared with southern Alberta during this period, Manitoba and Saskatchewan had higher rates of HIV cases in care (RR 1.88 and 2.04, respectively). When stratified according to province, there were significant increases in new HIV cases to care in Saskatchewan (RR 1.14) and southern Alberta (RR 1.25), while a significant increase in Manitoba was not observed. In addition, southern Alberta (RR 3.05) and Manitoba (RR 2.25) showed significantly more new male cases to care, whereas in Saskatchewan there were no significant differences between the rates of males and females.

Demographic and risk factors among patients at first presentation to care

In 2007, there were 222 new HIV cases to care across the provinces, with significantly more men than women $(\mathrm{P}<0.0001)$. The majority of 
TABLE 4

Descriptive characteristics of the new HIV-positive cases for 2007 according to province

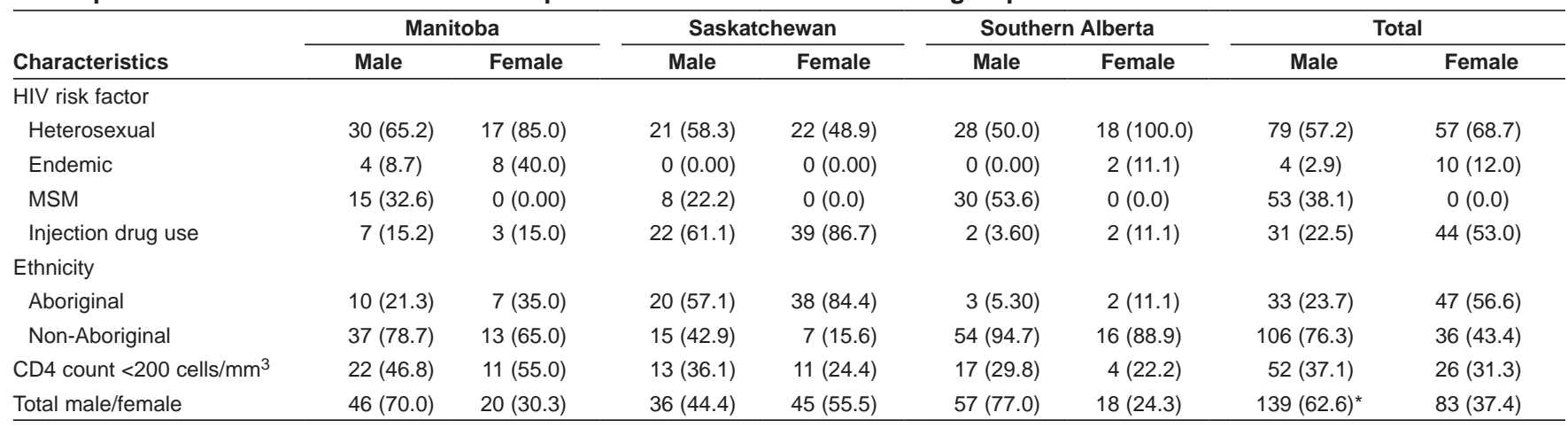

Data presented as $n$ (\%). *Significantly more men than women, $P<0.0001$. MSM Men who have sex with men

patients presenting to care in 2007 across the prairies were in the younger age group. The most common age category among cases newly accessing care was 18 to 39 years $(51 \%)$.

Table 4 shows detailed data on HIV-positive cases who were new to care in 2007. Heterosexual transmission was the most commonly reported risk category for transmission across the sites among both men and women, followed by IDU, although variability was seen across the provinces and between sexes. Compared with Saskatchewan and Alberta, a larger proportion of HIV cases in Manitoba was reported to be from HIV-endemic countries $(\mathrm{P}<0.0001)$, but this was mainly among women. Saskatchewan had a relatively high rate of IDU as the primary risk factor for transmission $(\mathrm{P}<0.0001)$, and southern Alberta had the highest proportion of MSM $(\mathrm{P}<0.0001)$, compared with the other two provinces. Heterosexual sex remained the most commonly reported mode of transmission across the prairies.

The Aboriginal population remains over-represented with approximately $36 \%$ of new cases self-reporting as Aboriginal, with Saskatchewan having the largest number of new cases identifying as Aboriginal compared with the other provinces $(\mathrm{P}<0.0001)$.

The mean and median CD4 count at presentation overall were 326 cells $/ \mathrm{mm}^{3}$ and 277 cells $/ \mathrm{mm}^{3}$, respectively. There was a statistically significant difference in CD4 count at presentation among the provinces. The median CD4 count at presentation in Manitoba was 203 cells $/ \mathrm{mm}^{3}$, while median CD4 counts in Saskatchewan and Alberta were 345 cells $/ \mathrm{mm}^{3}$ and 296 cells $/ \mathrm{mm}^{3}$, respectively $(\mathrm{P}=0.005)$. Additional information on clinical status at time of presentation is shown in Table 4. Late presentation was common, with almost 35\% of new cases presenting with CD4 counts of less than 200 cells $/ \mathrm{mm}^{3}$. By province, fewer persons presented with CD4 counts of less than 200 cells $/ \mathrm{mm}^{3}$ in Alberta and Saskatchewan (28.4\% and 29.6\%, respectively) compared with $50.0 \%$ in Manitoba (P=0.01). Approximately equal numbers of Aboriginals and non-Aboriginals presented with CD4 counts of less than 200 cells $/ \mathrm{mm}^{3}$ (36.3\% compared with $34.5 \%, \mathrm{P}=0.79$ ). After controlling for sex and ethnicity, with multivariate analysis, combining a CD4 counts of less than 200 cells $/ \mathrm{mm}^{3}$ and the presence of an OI at presentation, persons from endemic countries and having MSM as a risk factor were less likely to present late compared with persons reporting heterosexual transmission as their risk factor for HIV transmission. Furthermore, persons from Manitoba remained more likely to present late to care (Table 5).

Overall, 38 persons (17\%) presented to care for the first time with an OI. Pneumocystis pneumonia was the most common OI (14 cases), followed by tuberculosis (five cases). Just over $20 \%$ of all new cases to care were coinfected with hepatitis $\mathrm{C}$ (as identified by polymerase chain reaction), $76 \%$ of whom disclosed a history of IDU as a risk factor for transmission.

\section{DISCUSSION}

There were approximately $2300 \mathrm{HIV}$-positive persons in care in the prairie provinces in 2007 , with increasing numbers of new diagnoses
TABLE 5

Determinants of late presentation to care by multivariate analysis (2007), $n=221$

\begin{tabular}{lc}
\hline Characteristic & Late presentation adjusted OR (95\% Cl) \\
\hline Heterosexual & 1.00 (reference) \\
From HIV-endemic country* & $0.27(0.07-0.98)$ \\
MSM* $^{*}$ & $0.39(0.18-0.84)$ \\
Injection drug use & $0.66(0.34-1.3)$ \\
Alberta/Saskatchewan & 1.00 (reference) \\
Manitoba* & $2.49(1.30-4.80)$ \\
\hline
\end{tabular}

${ }^{\star} P<0.05$. MSM Men who have sex with men

over the past five years. This is in contrast to national trends, where a stabilization in the number of new positive tests was reported in $2008(1,6)$. Women account for greater than one-quarter of the current cases in care, also slightly higher than the national average $(1,2)$. Of the new cases to care in 2007, women accounted for more than $37 \%$.

Diversity is seen across the prairie provinces with Saskatchewan having the greatest proportion of HIV-positive women currently in care. As well, risk factors for transmission varied across the provinces. Overall, heterosexual transmission accounted for much of the transmission; however, Saskatchewan had the greatest number of new cases reporting IDU as their risk factor and Alberta saw a high proportion of MSM activity.

High rates of HIV infection are being seen among the Aboriginal population in the prairie provinces. Approximately $36 \%$ of new cases overall self-report as Aboriginal, which is significantly higher than the national average of $21.4 \%$ (1). Although American Indians and Alaska Natives only account for less than $1 \%$ of infections in the United States, when population size is taken in to account, they rank third behind African Americans and Hispanics (7). A study from British Columbia (8) reported that HIV-infected Aboriginal persons had an increased risk of mortality. In addition, other studies $(9,10)$ have demonstrated lower uptake and longer time to access care among the Aboriginal population in Canada. The present study did not demonstrate significantly higher rates of Aboriginals presenting with CD4 counts of less than $200 \mathrm{cells} / \mathrm{mm}^{3}$, but there remains an over-representation of Aboriginal persons infected with HIV and further research is required to understand the factors influencing the outcomes of Aboriginal HIV-positive persons in care in this region.

Overall, significant numbers of HIV-infected persons presented late to care in the prairie provinces with serious OIs, which has also been demonstrated in other Canadian epidemiological reports (11). In Manitoba, one-half of the new cases to care presented with CD4 counts of less than 200 cells $/ \mathrm{mm}^{3}$, which is by definition AIDS. Late diagnosis is associated with increased risk for morbidity and mortality $(12-14)$ and has an impact on the degree and extent of CD4 recovery 
(15). Furthermore, with delayed diagnosis, there is increased opportunity for onward transmission of HIV (13). Current guidelines recommend initiation of antiretroviral treatment when the CD4 count is equal to or below $350 \mathrm{cells} / \mathrm{mm}^{3}$, and two recent studies have suggested a benefit to starting antiretroviral treatment even earlier (16-19). Clearly, more work needs to be undertaken to develop approaches to facilitate earlier HIV diagnosis, linkage and engagement in care. Expanded testing options, harm reduction programs and broader positive prevention messages need to be considered.

The present study was limited by its retrospective nature becasue it only provides a snapshot in time of trends in HIV transmission and clinical care in the prairie provinces. Furthermore, the present study only captured information on HIV-positive persons presenting to care. As well, we only captured limited data regarding ethnicity; however, data were gathered by self-report. To our knowledge, the present study is the first to describe the distribution or risk among HIV-positive

\section{REFERENCES}

1. Public Health Agency of Canada. HIV and AIDS in Canada: Surveillance Report to December 31, 2007. Ottawa: Public Health Agency of Canada, 2007.

2. Public Health Agency of Canada. HIV/AIDS Epi Updates, Nov 2007. Ottawa: Public Health Agency of Canada, 2007.

3. Statistics Canada. Aboriginal identity population by age groups, median age and sex, 2006 counts for both sexes, for Canada, provinces and territories - 20\% sample data. Ottawa: Statistics Canada, 2006.

4. Statistics Canada. Population by immigrant status and period of immigration, 2006 counts, for Canada, provinces and territories 20\% sample data. Ottawa: Statistics Canada, 2006.

5. Statistics Canada. Table 051-0001 - Estimates of population, by age group and sex for July 1, Canada, provinces and territories, annual (persons) 2006. Ottawa: Statistics Canada, 2006.

6. Public Health Agency of Canada. Summary: Estimates of HIV prevalence and incidence in Canada, 2008. Ottawa: Public Health Agency of Canada, 2008.

7. Hall HI, Song R, Rhodes P, et al. Estimation of HIV incidence in the United States. JAMA 2008;300:520-9.

8. Lima VKP, Palepu A, Bonner S, et al. Aboriginal status is a prognostic factor for mortality among antiretroviral naïve HIV-positive individuals first initiating HAART. AIDS Res Ther 2006;3:14.

9. Plitt S, Singh A, Jayaraman G, Houston S, Lee B. Time to testing and accessing care among a population of newly diagnosed patients with HIV with a high proportion of Canadian Aboriginals. AIDS Patient Care STDs 2009;23:93-9.

10. Wood E KT, Palepu A, Zhang R, et al. Slower uptake of HIV antiretroviral therapy among Aboriginal injection drug users. J Infect 2006;52:233-6. patients in the prairie provinces. These clinics provide the majority of care to HIV-positive persons who are aware of their status in Manitoba, Saskatchewan and southern Alberta and, therefore, the present study provides a good overview and description of the individuals currently accessing HIV care in these provinces.

After more than two decades of increasing investment and response effort, the global HIV epidemic continues to expand. This is true in the prairie provinces, where we have observed increasing numbers of cases over the past five years with a substantial proportion of cases presenting late to care. In addition to an increase in testing campaigns, prevention efforts need to be scaled up and targeted to address at-risk populations, to ensure earlier diagnosis and clinical care.

ACKNOWLEDGEMENTS: This work was supported by Gilead Canada. The views expressed herein are those of the authors and do not necessarily reflect the official policy or position of Gilead Canada.

11. Hall HGJ, Boulos D, Rhodes P, et al. Epidemiology of HIV in the United States and Canada: Current status and ongoing challenges. J Acquir Immune Defic Syndr 2009;51(Suppl 1):S13-20.

12. Fisher M. Late diagnosis of HIV infection: Major consequences and missed opportunities. Curr Opin Inf Dis 2008;21:1-2.

13. Paltiel AD, Walensky RP, Schackman BR, et al. Expanded HIV Screening in the United States: Effect on clinical outcomes, HIV transmission and costs. Ann Intl Med 2006;145:797-806.

14. Althoff KN, Gange SJ, Klein MB, et al. Late presentation for human immunodeficiency virus care in the United States and Canada. Clin Infect Dis 2010;50:1512-20.

15. Robbins GK, Spritzler JG, Chan ES, et al; AIDS Clinical Trials Group 384 Team. Incomplete reconstitution of T cell subsets on combination antiretroviral therapy in the AIDS Clinical Trials Group protocol 384. Clin Infect Dis 2009;48:350-61.

16. Panel on Antiretroviral Guidelines for Adults and Adolescents. Guidelines for the use of antiretroviral agents in HIV-1-infected adults and adolescents. Department of Health and Human Services. $<$ http://aidsinfo.nih.gov/contentfiles/Adult andAdolescent GL001226.pdf> (Accessed on August 5, 2009).

17. Hammer SM Eron JJ Jr, Reiss P, et al; International AIDS SocietyUSA. Antiretroviral treatment of adult HIV infection: 2008 recommendations of the International AIDS Society-USA panel. JAMA 2008;300:555-70.

18. Kitahata MM, Gange SJ, Abraham AG, et al; NA-ACCORD Investigators. Effect of early versus deferred antiretroviral therapy for HIV on survival. N Engl J Med 2009;360:1815-26.

29. When to Start Consortium. Timing of initiation of antiretroviral therapy in AIDS-free HIV-1-infected patients: A collaborative analysis of 18 HIV cohort studies. Lancet 2009;373:1314-6. 


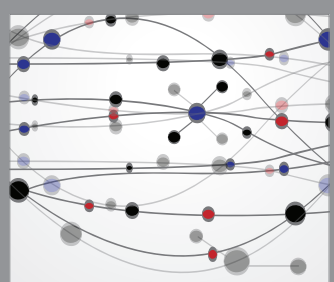

The Scientific World Journal
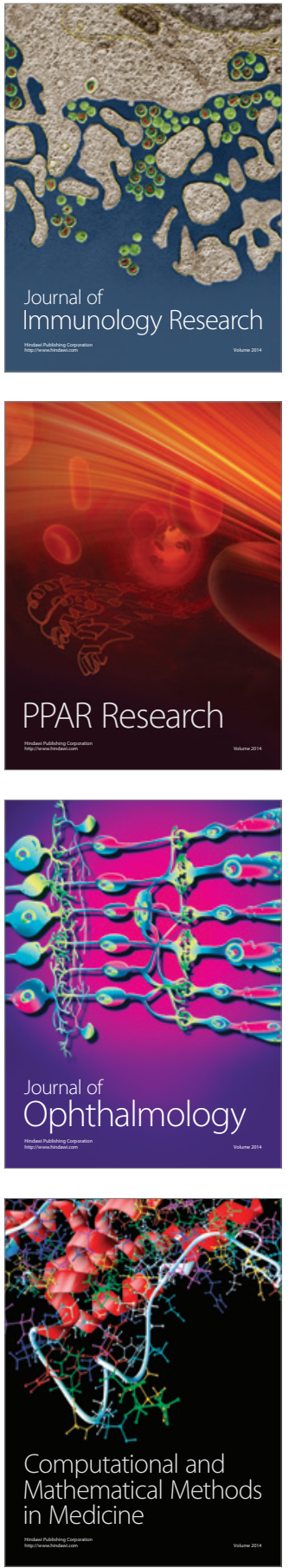

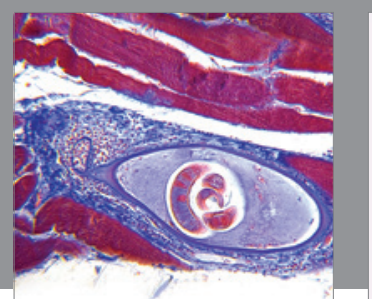

Gastroenterology Research and Practice

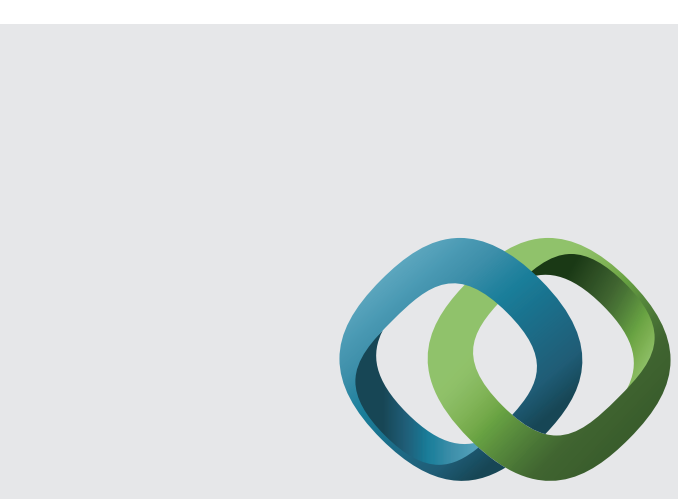

\section{Hindawi}

Submit your manuscripts at

http://www.hindawi.com
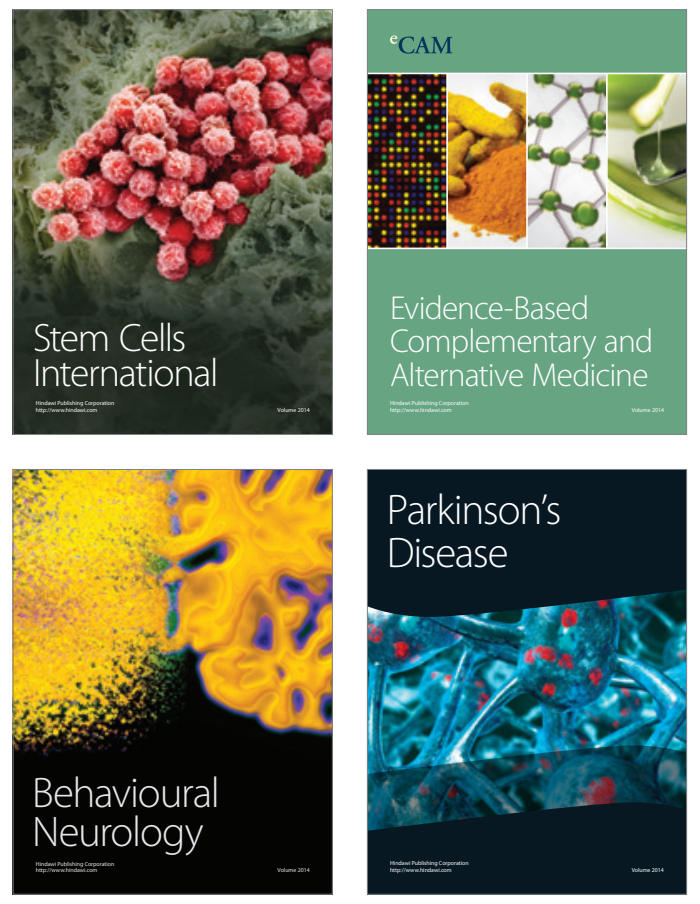
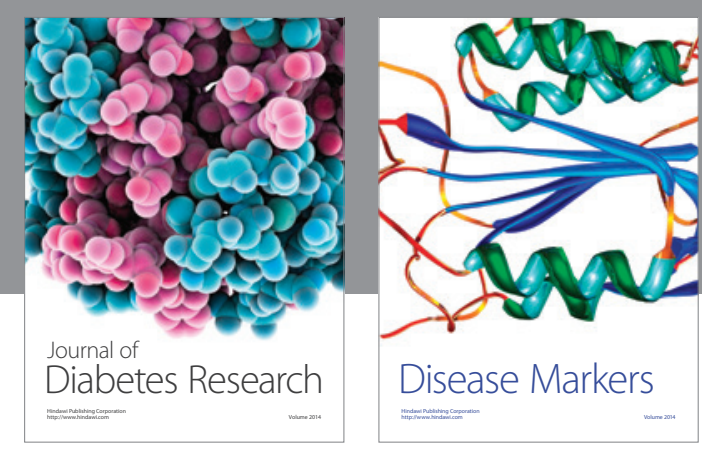

Disease Markers
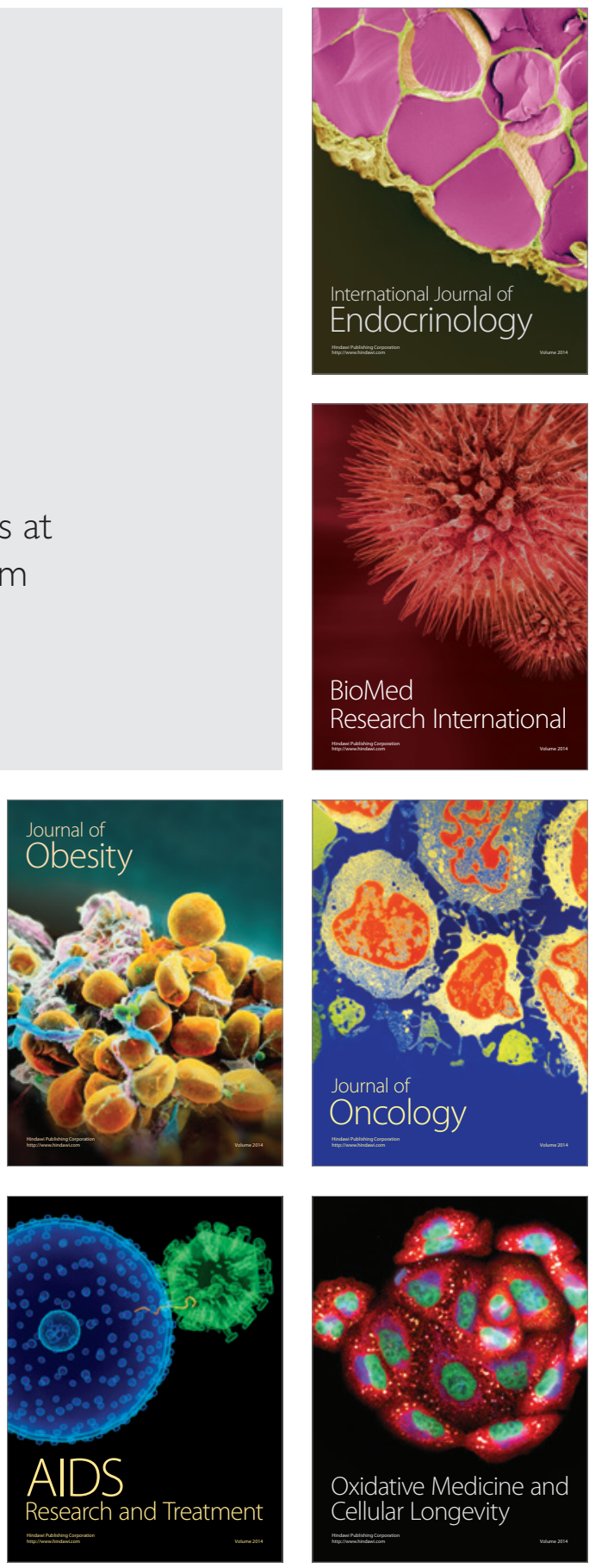